\title{
UN Peace Operations: Adapting to a New Global Order?
}

\author{
Mateja Peter
}

\section{A New Global Order?}

In early March 2015, the United Nations (UN) Secretary-General's High-Level Independent Panel on UN Peace Operations (HIPPO) made a stop in Cairo, Egypt as part of its regional consultations on reform of UN peace operations. One of the discussion questions for the first session asked, whether current UN peace operations in the Middle East are the right fit for today's security environment and, if not, what kind of UN presence makes the most sense now and in the future. Very soon into the session a young diplomat from one of the regional states challenged the premise of this question, arguing that the only role for the $\mathrm{UN}$ is in supporting regional approaches. His passionate intervention opened a floodgate, with speaker after speaker depicting the UN with deep suspicion. The message was clear: UN peace operations were seen to be a Western intervention into regional matters; the League of Arab States (LAS) should deal with Arab problems, same as the African Union

\section{Peter $(\bowtie)$}

School of International Relations, University of St Andrews, St Andrews, UK e-mail: mp240@st-andrews.ac.uk

(C) The Author(s) 2019

C. de Coning and M. Peter (eds.), United Nations

Peace Operations in a Changing Global Order, https://doi.org/10.1007/978-3-319-99106-1_1 
(AU) should deal with African ones. The primacy of the UN was under challenge. Two years later, with the number of crises in the world not subsiding, the United States (US), as not only the leader of the Western world but also the biggest funder of UN peacekeeping, sought to cut $\$ 1$ billion from the UN peacekeeping budget (Lynch 2017). Moments after the budget was adopted, the US ambassador to the UN exclaimed on twitter: "Just 5 months into our time here, we've cut over half a billion $\$ \$ \$$ from the UN peacekeeping budget \& we're only getting started" (Green 2017). All this is happening at a time, when UN peace operations are marred in sexual abuse scandals (UN 2015a; Essa 2017; Naraghi Anderlini 2017), hence losing legitimacy in the eyes of the global public and, more consequentially, the local population, which they are supposed to be serving. Local and global non-state actors are demanding accountability and the $\mathrm{UN}$ is increasingly forced to react. For example, in June 2017, after a non-governmental organisation (NGO) Aids Free World leaked internal UN documents detailing alleged sexual abuse and misconduct, the UN announced the withdrawal of 600 Congo-Brazzaville peacekeepers from the UN Mission in the Central African Republic (CAR) (UN 2017). Challenges are coming from all sides and the core dilemma addressed by this volume is whether and how UN peace operations are adapting to this new global order.

Since the turn of the century both conflicts and interventions have changed dramatically. Self-perpetuating cross-border conflicts fuelled by both greed and grievances (Berdal and Malone 2000; Collier and Hoffler 2004) - a key feature of the post-Cold War security environment-, have gained new dimensions with the rise of illegitimate non-state actors. Groups such as ISIS in Iraq and Syria, Al-Shabaab in Somalia, al-Qaeda-affiliated groups in northern Mali, Boko Haram from Nigeria, the Lord's Resistance Army from Uganda or the M23 militia in the eastern Democratic Republic of Congo (DRC) are rewriting the rules of war. These groups are not just spoilers of peace agreements (Stedman 1997), they are seen as antithetical to peace agreements: neither they nor the broader international community are interested in peace agreements that would include them (Peter 2015, p. 358). The scale and nature of their atrocities in their regions of origin and the fact that many of them have a global reach through terrorist activities, makes the international community, as a whole, and members of the UN Security Council (UNSC), more specifically, unlikely to allow them any legitimate claims. Despite this wide agreement, the UNSC is often at odds about the kind of action 
that should be taken to address their rise, something we have best seen in Syria. In other regions, where the permanent members of the UNSC have less polarising positions, UNSC responses indicate a new trend in interventions. Whether conducted through UN peacekeeping operations, such as in Mali, the DRC and the CAR, or through regional organisations, such as in Somalia or through the Multinational Joint Task Force against Boko Haram (de Coning et al. 2016), international responses are increasingly robust.

These new types of conflicts and interventions are happening at a time of dramatic shifts in the global order. For much of the twentieth century, the discourse on peace and security took place between the East and the West, tempering the UN's ability to get involved in intra-state conflicts. With the end of the Cold War and the newly found agreement in the UNSC, peacekeepers began addressing fallouts from civil wars and assisting post-conflict states in their reconstruction. But the much-hailed 'end of history' (Fukuyama 1992) resulting in the liberal 'peacebuilding consensus' (Richmond 2004), did not transpire in ways anticipated. This new century is one of North-South rebalancing. From bipolar, via unipolar, we have now entered a truly multipolar world (de Coning et al. 2014; Narlikar 2010). States from the global South have long been active participants in peacekeeping as troop and police contributors. This has not changed. At the time of writing, the top ten troop and police contributing countries are all from the global South, with Ethiopia, Bangladesh, India, Rwanda and Pakistan topping the list. ${ }^{1}$ Throughout the history of UN peace operations, the role of these states in the field has not been matched by their participation in decision and policy making, with experts calling this division of work between the North and the South "a blue helmet caste system," (Lynch 2013) "apartheid," (Chesterman 2004, p. 11), and "imperial multilateralism" (Cunliffe 2013 , p. 20). This is changing. States of the global South are not mere recipients and implementers of international interventions anymore, but are increasingly vocal about how these should take shape.

This rise of the global South is accompanied through and aided by the emergence of regional organisations as providers of security. During the second half of the twentieth century, the UN peacekeeping missions were often considered as the only viable and legitimate actor in

\footnotetext{
${ }^{1}$ The only OECD country among the top 20 contributors in February 2018 was Italy in the 20th place (UN 2018).
} 
managing conflicts. This idea of an objective and unbiased respondent is enshrined in one of the key principles of UN peacekeeping: impartiality (UN 2008). Over the last two decades, due to both stalemates in the UN Security Council and the changing nature of conflicts, regional organisations, both from the global North and South, frequently became the first responders. The most striking of these is still the 1999 intervention in Kosovo, where the North Atlantic Treaty Organisation (NATO) responded to an escalating humanitarian crisis despite objections from Russia and China (Holzgrefe and Keohane 2008). Unlike the Kosovo intervention, other regional organisations' missions, from Somalia to the CAR and Mali, as a rule, received prior authorisation from the UNSC. With a notable exception of Libya, the UNSC authorisation now tends to follow a host state invitation to a regional organisation. The host states are often not seeking an impartial actor, but one that can deal with their internal problems efficiently. Responses to contemporary conflicts are increasingly robust and regional organisations are better equipped than the UN to execute them. But more and more it is not just the efficiency but also the legitimacy of the regional organisation over the UN that plays the role in the determination of an intervening actor. Sudan, for example, refused a deployment of a pure UN peacekeeping operation to Darfur and instead asked for a joint United Nations-African Union Mission in Darfur (UNAMID) (Burkeman and Rice 2006). In other cases, the fact that regional organisations responded first as peace enforcers brought them the legitimacy in the peacekeeping phase. Even when the UN deploys to the same area, regional organisations remain important players on the ground. In Mali and the CAR, Economic Community of West African States (ECOWAS) and AU troops, respectively, who were on the ground first, simply got re-hatted into UN troops (Williams and Boutellis 2014). Responses to conflicts today are more multifaceted than they were two decades ago. What this means for the primacy of the UN, as enshrined in the UN Charter, remains to be seen.

This rebalancing of relations is not only happening between the member states or the inter-governmental organisations, increasingly it is the non-state actors that put pressures on the international community to respond to atrocities. The plight of human populations half across the world and the inaction or inappropriate responses of states are not merely televised as they were directly after the Cold War, but are shared immediately and unfiltered on social media. These technological 
advances, combined with the post-Cold War spread of human rights ideas, mean that-at least in the eyes of non-state actors-the standards for what peace operations are supposed to achieve are higher than ever. The message from global and local non-state actors is clear: the main objective of peace operations should be improving security and well-being of people affected by conflicts. Interventions should not focus only on state security, but also improve human security (Suhrke 1999; Stoett 1999; Paris 2001). When peacekeepers get embroiled in abuse and misconduct scandals, their legitimacy is tainted from the start. While new technology has changed how the UN is responding to conflicts, it has also facilitated greater transparency over what peace operations are achieving and when they are failing.

In sum, global order is facing four key transformations, collectively presenting unique challenges to UN peace operations: (1) the rebalancing of relations between states of the global North and the global South; (2) the rise of regional organisations as providers of peace; (3) the rise of violent extremism and fundamentalist non-state actors; and (4) increasing demands from non-state actors for greater emphasis on human security.

\section{United Nations Responses}

The challenges the above transformations present are in many ways new for the UN, demanding a rethinking of some of the core assumptions of what peace operations can achieve and what they should be aiming to do. However, this is not the first time that the UN and the international community have had to rethink their approaches to peace and security. Throughout the 1990s and in the early 2000s, the UN was rethinking what role its peace operations should serve in the post-Cold War environment, culminating in the debates around the Brabimi report (UN 2000). The findings in the Brahimi report have shaped our understanding of modern multidimensional peace operations and led to institutional changes within the UN that continue today. Arguing for clear, credible and achievable peacekeeping mandates, the report also cemented the idea of longer-term peacebuilding approaches as part of effective peacekeeping. But the Brahimi report and debates around it were to a large extent a response to the challenges the UN was experiencing in the 1990s - from the disastrous international intervention in Somalia and the failure to prevent genocides in Bosnia and Herzegovina and Rwanda, to 
the then relatively novel emphasis on institution- and state-building as a method to build peace. Brahimi precedes the 9/11 terrorist attacks in the US, the intervention in Afghanistan, and the international rift over Iraq; it also precedes the idea of the BRICS ${ }^{2}$ and even the formation of the AU, as well as the global financial crisis of 2008 and the emergence of fundamentalist non-state actors and violent extremism as one of the biggest perceived threats to the international peace and security. It is evident that much has changed in both the nature of conflict and international responses to it since the turn of the century.

Contemporary peace operations and the UN are faced with a challenging task of having to reconcile the post-Brahimi development of policies and thinking about human security, protection of civilians, local ownership, gender inclusivity, and longer-term institution-building, with the new realities of conflict and intervention. There are pressures to achieve more to assist states and people embroiled in or emerging from conflicts. At the same time, the UN is under pressure to include an increasing array of voices from within its membership. Each of these voices is advancing their own vision of interventions and with that also their own vision of UN peace operations. How do peace operations ensure legitimacy in the eyes of the local populations and the global public, while at the same time serving the interests of member states? Are the interests of member states compatible with the interests of the international community as a whole? How to balance between state and human security; between short-term solutions and long-term approaches? These questions arise in an era where regional organisations are emerging as possible alternatives to the UN, further pushing the UN to justify the relevance of its own peace operations. That previously advanced approaches linking peacekeeping with peace- and state- building have not had the desired effects on peace consolidation, is putting an additional pressure on the UN to reform (Heathershaw 2008; Campbell et al. 2011; Mac Ginty 2012).

In October 2014, aware of the implications all these developments are having on UN peace operations, the former Secretary-General Ban Ki-moon appointed the High-Level Independent Panel on UN Peace Operations (HIPPO) (UN 2014). The expert panel was to produce a report akin to the Brahimi report and was encouraged by the SecretaryGeneral and other senior figures in the UN to be bold and creative in

\footnotetext{
${ }^{2}$ BRICS acronym is used for emerging powers Brazil, Russia, India, China and South Africa and was coined by the chief economist for Goldman Sachs (O’Neill 2001).
} 
its recommendations. While members of the panel were appointed in their personal capacity, the composition of the panel showed that the Secretary-General had regional balance and the changing global order in mind. All five permanent members of the Security Council were represented. In addition, there were three representatives from Africa (Tunisia, Ghana, Burundi), three South Asian members (India, Bangladesh, Sri Lanka), three key financial contributors (Norway, Canada, Australia), as well as representatives from Latin America (Brazil) and the Middle East (Jordan). The panel-working under the leadership of the Nobel Laureate and former President of Timor-Leste Jose RamosHorta- delivered its report in June 2015 (UN 2015b).

The HIPPO report reviews past engagements and maps out future directions for UN peace operations by proposing four "fundamental shifts" that the UN needs to undertake to remain relevant: (1) primacy of politics: peace operations should be underpinned by political solutions, and not military and technical engagements; (2) a spectrum of peace operations: the UN should deliver more tailored 'right fit' and not 'template' missions that better take into account specificities of the situation; (3) a global and regional partnership for peace and security: the UN should embrace the era of partnership with regional organisations and national capacities and use their comparative advantages; and (4) more field-focused UN Secretariat and more people-centred UN peace operations (UN 2015b).

These four core recommendations reflect the changing nature of conflict as well as a global re-ordering. The first two recommendations can to a large extent be interpreted as a response to the rise of violent extremism; they reflect the reality that peace operations are now often deployed to areas where there is no peace to keep. Technical solutions and bureaucratic approaches have a limited scope in such situations. These two recommendations are undoubtedly also a reaction to the critiques in both scholarly and policy literature, which have long argued against one-size-fits-all approaches and encouraged conflict sensitivity. The third fundamental shift proposed by the HIPPO panel reflects the changing role of the UN in the world. Calling for an era of partnership with regional organisation-and singling out Africa in the remainder of the report-is a good indication that the panel was aware that the UN is not necessarily the most effective or legitimate actor in many areas of the world. The last and in many ways the most ambitious shift reminds both the UN and member states that in the end, the UN and its peace 
operations will only remain relevant to the extent that they successfully respond to the expectations of people. The preface of the document is couched in the language of peace operations serving people, not just states, showing that the panel tried to reconcile the aspirational with what is feasible. As the panel was carefully selected to reflect the current global order, its report and responses to it are a good indication of what the international community could agree upon at the aspirational end of the spectrum. Whether that is enough for the UN to respond to the pressures emanating from changes in the global order to retain its relevance for the twenty-first century is another question altogether.

\section{Four Transformations in Global Order and Their Implications on UN Peace Operations}

This edited volume generates a discussion about UN approaches to peace by studying challenges and opportunities that the organisation is facing in the twenty-first century. We use some of the findings from the HIPPO report as an inspiration and put both its recommendations and broader UN actions in a wider context. We identify four transformations in the global order and study what implications these have on UN peace operations. The first two transformations emanate from the changing relations between states and reflect the increasingly multipolar character of contemporary global governance. The latter two transformations reflect the changing relations between state and non-state actors. These two broad groups of non-state actors are fundamentally incompatible in their outlook on how and whether the international community should be intervening. That notwithstanding, both groups of non-state actors also force the UN and its member states to rethink the centrality of statebased approaches to security and intervention.

In this volume, we identify four transformations in the global order and study their implications on the United Nations peace operations. We ask:

- How is the rebalancing of relations between states of the global North and the global South impacting the UN's decision-making, financing and ability to design operations that go beyond the minimum common denominator;

- How is the rise of regional organisations as providers of peace impacting the primacy of UN peace operations and how and whether the UN can remain relevant in this era of partnership and competition; 
- How have violent extremism and fundamentalist non-state actors changed the nature of international responses and what does this mean for previously advanced longer-term approaches to conflict resolution;

- How are demands from non-state actors for greater emphasis on buman security impacting the UN's credibility, and whether, in light of the first three transformations, the UN is even able to prioritise people-centred approaches over state-centred ones.

Our core finding is that with the entry of new actors from the global South as important players in the peace arena, we seem to be entering a more pragmatic era of $U N$ peace operations. As contributions to this volume show, there is a greater willingness to innovate and experiment with new forms of conflict management, including more robust interpretations of UN peacekeeping and an increasing reliance on regional actors as providers of peace. At the same time, the UN is facing a classic struggle between the promotion of liberal international norms and realist security concerns. The resolution of this struggle is less clear. The contributors to this volume emphasise the importance of people-centred approaches, conflict sensitivity and longer-term thinking as key aspects to continued relevance of the UN, but their conclusions as to how achievable these are by the UN are not as clear cut.

\section{New Vocabulary for a New Era}

The terminology of (post-) conflict intervention is confusing and confused. Even experts in international relations would be hard pressed to explain the difference or the similarity between peacekeeping and peacebuilding and often equate the two without much thought. ${ }^{3}$ Similarly, in UN hallways, many would find it difficult to articulate any difference between peace operations and peacekeeping. As international interventions diversify, new terms emerge. The following paragraphs won't resolve this confusion; their intention is to operationalise terms used in this volume as well as to indicate why the UN vocabulary is changing.

\footnotetext{
${ }^{3}$ As a rule, the more problem-solving approaches will tend to refer to an activity as peacekeeping to focus on the more time-defined engagement and on the missions, themselves, with critical approaches referring to the same activity as peacebuilding to capture the broader context (Cox 1981; Pugh 2004).
} 
In line with the broader argument of the book, we see these adaptations in UN language as a manifestation of the more pragmatic approach the UN has taken in recent years. This pragmatism is paradoxically addressing many of the critiques about rigidity of UN peacekeeping coming both from policy circles and critical literature.

Contemporary lexicon of UN operations can be found in the Capstone doctrine (UN 2008). This document situates peacekeeping-an activity it aims to operationalise-on the spectrum of peace and security activities. Peacekeeping is defined as "a technique designed to preserve the peace, however fragile, where fighting has been halted, and to assist in implementing agreements achieved by the peacemakers" (ibid., p. 18). Peacekeeping is to follow and to some extent overlap any peacemaking and peace enforcement activities. Peacemaking involves diplomatic activities to bring hostile parties to the negotiated agreement and can be conducted by either the UN itself, regional organisations, states or non-governmental actors. Such activities would fall under Chapter VI of the UN Charter. Peace enforcement involves the use of a range of coercive measures, such as sanctions or the military force, intended to halt the conflict and bring warring parties to the negotiating table. These are the so-called Chapter VII actions authorised by the UN Security Council. Both peacemaking and peace enforcement are striving for the same outcome: a ceasefire. As peacekeeping sits in-between and succeeds both peacemaking and peace enforcement, it is often referred to as a 'Chapter VI and a half' tool. The UN sees peacekeeping as one element of post-conflict peacebuilding activities, which constitute "a complex, long-term process of creating the necessary conditions for sustainable peace" (ibid.). These peace and security activities seldom occur in a linear or sequential manner, showing linkages not only between different international actors but also between different parts of the UN.

In addition to peacekeeping operations, special political missions (SPM) have come to play an important role in how the UN engages in its peace activities. In February 2018, the UN had 25 SPM operations deployed across Africa, Central Asia, and the Middle East. ${ }^{4}$ This was in addition to the 15 peacekeeping ones. ${ }^{5}$ The Capstone doctrine doesn't list special

\footnotetext{
${ }^{4}$ For a full list of current SPMs see http://www.un.org/undpa/en/in-the-field/overview.

${ }^{5}$ For a full list of current peacekeeping operations see https://peacekeeping.un.org/en/ where-we-operate.
} 
political missions as part of UN peace and security activities, but considers them as a type of operation that may precede or be deployed alongside a peacekeeping operation (ibid., p. 87). These missions engage in conflict prevention, peacemaking, and peacebuilding and therefore do not fit neatly on the spectrum of peace and security activities. Unlike peacekeeping operations, which necessarily include a military component, SPM operations are smaller. Some of them have regional mandates-for example, the UN Office for West Africa and the Sahel (UNOWAS) or the UN Regional Centre for Preventive Diplomacy for Central Asia (UNRCCA). Others may be deployed to conflict-ridden countries, where it would be difficult to obtain consent of the host state or the UN Security Council for a deployment of a UN military mission. The clearest examples of these today are the missions to Yemen and Syria.

While often taking on many of the same tasks, peacekeeping operations and special political missions are managed by two separate departments within the UN Secretariat, the Department for Peacekeeping Operations (DPKO) and the Department of Political Affairs (DPA), respectively. Peacekeeping operations have their own separate budget (the so-called assessed contributions) and have therefore somewhat more predictable funding and planning cycles (Diehl and PharaohKhan 2000). In contrast, SPMs are funded through the regular UN budget. To rapidly respond to crises unanticipated in the regular budget, SPMs are increasingly reliant on extra-budgetary resources. These voluntary contributions fund about $40 \%$ of DPA's work today. ${ }^{6}$ Funding and management disparities were one of the main reasons why the most recent review of peace operations recommended to make away with the sharp distinction between peacekeeping operations and special political missions. The HIPPO report strongly urges the UN to embrace the term peace operations to signify the full spectrum of responses required (UN 2015b, p. viii). Such change in thinking would bring peacekeeping and SPMs under one label, a move that could eventually pave the way for the reform in financing and management of UN responses. It would also allow for more fundamental changes to the structure of individual missions over time, including more clearly sequenced mandates.

More importantly for the argument of this book, the term peace operations also better denotes changes that UN responses to conflicts

\footnotetext{
${ }^{6}$ For an overview of voluntary contributions see http://www.un.org/undpa/en/funding.
} 
have undergone, as well as changes the UN would need to implement if it wants to remain relevant in responding to contemporary conflicts. Both policy and scholarship have long been critical of the rigidity of UN peacekeeping, calling for a greater local sensitivity and development of tailor-made approaches. Not all conflict responses require a large military component to keep peace. Others might be best addressed through a deployment of a military component to a whole region, not just a single state. Some peace operations are closer in their activities to peace enforcement, others to peacebuilding. Their mandates and composition need to reflect this reality and not follow bureaucratic templates. A comprehensive reform of UN financing is highly unlikely in the current political climate. As a result, the UN Security Council will almost certainly continue privileging peacekeeping operations, when it wants to provide a comprehensive UN response. Recognising this political reality, authors in this volume nonetheless emphasise the increasing diversity of existing approaches and the need for a greater context-sensitivity of international responses to conflicts. Both critical and policy-oriented contributions share this sentiment. Terms and categories used by both policymakers and scientists serve as political tools. Although individual authors highlight particular processes through their own terminology, the volume as a whole embraces the broader analytical category of peace operations. We chose to use it in the title of the volume to highlight the diversity of international approaches to conflicts and the need to go beyond technocratic solutions.

\section{Aims of THE Book}

This edited volume offers a comprehensive review of challenges and opportunities the UN peace operations are facing in the twenty-first century. It serves as a conversation between scholars and practitioners, with an intent to capture experiences of both. Despite an increasingly active interest in UN peace operations and third-party interventions in public and scholarly discourse, much of these discussions operate in parallel to policy discussions. Public debates focus on sensational stories and failures of the UN, ascribing these to organisational inadequacies. On the other hand, much of the scholarly literature operates with an insufficient understanding of the dramatic changes in the global context, nature of conflicts, and international responses that have occurred over the past decade. Many of the policy developments and debates do not 
reach the ivory towers. This volume uniquely tries to bring recent developments in policy as well as practitioners' debates on the future of the UN peace tools to the scholarly community. We have invited two former Special Representatives of the Secretary-General and members of the HIPPO panel to reflect on areas of peace operations they are passionate about-people-centred approaches and protection of civilians. At the same time, the volume provides for a reflexive engagement on recent policy developments from academic authorities from both the global North and South. It situates policy debates in the global reordering and provides an idea of where the UN and the broader international responses to conflicts are heading in the medium-term future. Through this conversation, the edited volume will be of interest to both practitioners and scholars.

Stressing different aspects of peace operations and partnerships, contributors to this volume collectively query the relevance and ambition of the UN and its peace operations. By examining the four shifts in the global order, the volume's ambition is to:

- Map recent developments in UN peace operations and assess where UN approaches to peace are heading;

- Analyse what kind of pressures the changing nature of conflicts is putting on UN peace operations and what alternatives to UN responses are emerging;

- Assess how changes in the global order are affecting UN peace operations and the role of the United Nations as a whole;

- Examine how the state of the art understanding about protection of civilians, local ownership, gender inclusivity and institution-building, can be accommodated in increasingly robust UN peace operations;

- Inform future debates in both scholarship and practice by providing innovative ideas for rethinking of UN approaches to peace.

\section{STRUCture OF THE BOOK}

This volume is divided into three parts, each combining voices of practitioners and scholars. The first part of the volume looks at the political and strategic context, situating current debates within a longer trajectory of UN interventions. It highlights major shifts in UN approaches to peace, emphasising pressures on peace operations coming from both 
state (emerging powers and regional organisations) and non-state actors. In the second part, authors examine mandates and strategy, highlighting some of the key changes UN peace operations have undergone in recent years as well as weighing in on the challenges that remain. While other equally important issues have been introduced to the agenda of UN peace operations in recent years (for example, women, peace and security or disarmament, demobilisation and reintegration), we prioritised developments that are putting major strain on the functioning of peace operations and are potentially changing the nature of UN approaches to peace. In the third part, contributors explore new and old partners to UN peace operations, querying how the UN relates to some other key players in contemporary interventions. While necessarily selective, this section's choice of UN partners (China, African Union, European Union and religious humanitarians) aims to underscore the complexity of UN partnerships with both state and non-state actors in the twenty-first century.

Part 1-Political and Strategic Context: Past, Present, Future-consists of four contributions. In Chapter 2, Mateja Peter examines the evolution of the idea of UN peacekeeping, asking how an instrument developed in the late 1940s managed to not only survive but also respond to the changing geopolitical and conflict landscape over the last seventy years. Through an overview of major doctrinal developments and institutional adaptations, she analyses how the peacekeeping tool was adapted from a bipolar world, via a unipolar one to today's multipolar world. The label of peacekeeping has encompassed very different activities over this period and peacekeeping today bears only casual resemblance to peacekeeping from decades ago. In her contribution, Peter argues that peacekeeping started as a conflict management instrument, which was adapted to a conflict resolution mechanism after the end of the Cold War, but has now come full circle and is again increasingly used to manage and contain, not resolve conflicts. And in this ability to adapt to the needs of the states and the changing global relations lies the resilience of the idea of peacekeeping itself.

In Chapter 3, Adriana Erthal Abdenur asks how the changing global order is impacting UN peace operations. She contends that the multipolarisation of the world order is accelerating, due to both the decline of Western powers and the increasing contestation of Western dominance by several rising powers. Throughout the chapter, Abdenur examines two inter-related implications of multipolarisation for UN peace 
operations: norms-setting and role expectations. Uncertainties about global leadership and constraints on resources prompt changing expectations of, and concern about, rising powers, especially those viewed as playing a pivotal role in UN security governance. She highlights China as a potential leader in UN peacekeeping, but contends that Beijing's willingness and ability to quickly expand its influence should not be taken for granted.

In Chapter 4, Adam Day turns his attention to UN's conflict prevention work, where politically-driven solutions have become more elusive. He traces how good offices have evolved from early Secretaries-General through the expansion of UN peace operations in recent decades. This lays the groundwork for a comparative analysis of modern applications of good offices in more recent conflicts, examining how the UN has attempted to reshape its political engagement to accommodate the changing nature of armed conflict. Based on a comparative assessment of the UN's political engagement across different settings and eras, Day lists four key elements for successful use of good offices: (1) in-depth understanding of the conflict based on sustained contact and relationships on the ground; (2) timing of the intervention; (3) leverage over the key conflict actors; and (4) credibility of the mediator. He contends that a light, nimble presence on the ground-rather than multidimensional peace operations - appear best placed to achieve these elements of success.

In Chapter 5, Youssef Mahmoud provides an impassionate argument for why UN peace operations should shift towards and prioritise people-centred approaches. Drawing on his experience as a former Special Representative of the Secretary-General and a HIPPO panel member, he contends there is a growing and wide recognition that peace, like a tree, grows from the bottom up, but that many challenges still stand in the way of realising this shift on the ground. In his contribution, Mahmoud provides a cursory review of the factors underpinning these challenges and explains the rationale of the Panel's renewed focus on people-centred approaches. He continues by reflecting on the conundrums faced by the UN Security Council in its attempts to embrace such an approach in a changing security landscape, providing concrete recommendations to the Security Council and member states.

Part 2-Mandates and Strategy-is composed of five chapters exploring recent developments in UN peace operations, all potentially changing the nature of UN approaches to peace. In Chapter 6, Mats Berdal 
explores the outer limits of the use of force by UN peacekeepers. He traces the thinking and the practices surrounding the use of force from the conceptual foundations laid in the era of classical peacekeeping to the contemporary focus on the protection of civilians and more "robust" operations. He contends that at the tactical level, a properly equipped and properly commanded force has on occasion been used with decisive effect in response to immediate crises or emergencies. In contrast to that, Berdal sees the larger and more critical strategic lesson from the history of robust peacekeeping since 1999 as a cautionary one; one that highlights the need for the activities of UN "blue helmets" to be much more closely aligned than they have become over the past decade and a half, to the search for viable political solutions to conflict.

In Chapter 7, Hilde Frafjord Johnson, a former Special Representative of the Secretary-General and a HIPPO panel member, shares her experience on a topic at the centre of UN peace operations: protection of civilians. Reflecting on the fact that today a vast majority of UN military and police personnel have a mandate to protect civilians, she queries whether UN operations are provided with the necessary means to fulfil this mandate. Drawing on her experience from the UN Mission in South Sudan (UNMISS), Frafjord Johnson reveals systemic weaknesses in the way the UN deploys, resources, and supports missions. A major problem is lack of guidance in cases where host governments prove to be the main perpetrator. Frafjord Johnson maintains that the primary responsibility to protect civilians rests with host governments, but that the UN system also needs to train its forces in protection of civilians operations and security reform, which has not been a priority so far. She concludes that protection will remain an illusion for many civilians at risk unless these challenges are addressed.

In Chapter 8, John Karlsrud looks at how UN peace operations have been responding to violent extremism and terrorism. He argues that there are practical and financial reasons to give UN peace operations more robust mandates to mitigate and respond to new threats. But the idea of UN peacekeepers conducting counter-terrorism operations is not without challenges. Karlsrud contends that UN peace operations neither are, nor will be ready operationally, doctrinally or politically to take on counter-terrorism tasks. Such a development could jeopardize the legal protection of UN staff; remove the ability of the UN to be an impartial arbiter of the conflict; and strongly undermine the ability for other parts of the UN family to carry out humanitarian work. However, UN 
peace operations should, in cooperation with the UN Country Team, strengthen their conflict prevention and early peacebuilding agenda, to remove root causes for radicalisation.

Chapter 9, co-authored by Arthur Boutellis and Stephanie Tiélès, examines how peace operations have responded to organised crime. While scholars have increasingly recognised the importance of criminal agendas in post-conflict politics, organised crime is still a relatively understudied and misunderstood issue in the field of peace operations. With their contribution, Boutellis and Tiélès examine how transnational organised crime has increasingly become recognised by the UN Security Council as a threat to international peace and security. They provide a thorough analysis of the limitations of the dominant law enforcement and capacity building approaches adopted by UN missions to date. Building on recent examples, they provide lessons on how UN peace operations could deal more effectively with the issue of organised crime, contending that missions need to engage more strategically with both the host state and local communities as well as identify strategic partners to take longer-term preventive approaches.

In Chapter 10, Kari M. Osland examines the role of police in UN peace operations. She observes that the increasing demand for UN police comes from the recognition that functioning local police is a central element of the UN exit strategy. However, reaching that point is very challenging. In her contribution, Osland contends that UN policing was never easy, but that the combination of an increasing deployment of UN operations in the midst of on-going wars and the steady increase of UN police tasks without adequate increases in resources or training, has made UN policing even more complicated in recent years. Examining both the security and trust role of police in society, she argues that the main challenge for UN police in post-conflict situations is to close the securitytrust gap. So far, most of the focus of UN operations has been on the security part of the equation. In this chapter, Osland asks whether the $\mathrm{UN}$ is even set up to achieve both.

Part 3-New and Old Partnerships-is composed of four chapters reflecting on the role of other actors in peace operations and the impact they have on the UN. In Chapter 11, Cedric de Coning examines Africa's increasing peace operations capacity. African states have deployed operations of their own and they now contribute half of all UN peacekeepers. De Coning argues that the AU and the UN have developed a strategic partnership that plays out at the political, policy, and operational 
levels, and reflects the reality that neither will deploy peace operations in Africa without close consultations and some form of cooperation with the other. While the UN peacekeeping model is not found to be wellsuited to enforcement, counter-terrorism or trans-national operations, de Coning argues that, the AU, sub-regional organisations and ad hoc regional coalitions have developed capabilities designed to address these challenges. These African capabilities help relieve the pressure on the UN to conduct such operations.

Chapter 12, authored by Thierry Tardy, looks at the evolving relationship between the European Union (EU) and UN peace operations. Tardy argues that over the last twenty years, the EU has become a prominent crisis management actor alongside and sometimes together with the UN within the field of peacekeeping. He locates the EU's crisis management role in the UN's general mandate of "maintaining international peace and security". Throughout the chapter, he grapples with questions such as: What is the EU's approach to managing crises? To what extent does the EU's approach converge with and support the UN peacekeeping agenda? And what do EU member states' own institutional choices tell us about the UN-EU global-regional peace and security partnerships? Tardy provides a comprehensive overview of EU crisis management operations, compares EU and UN operations, and sheds light on the causes of this cooperation and its consequences for their relationship. Finally, he assesses the European participation in the UN operation in Mali and suggests how EU member states' institutional preferences may evolve in the coming years.

In Chapter 13, Yin He turns attention to China's rising prominence in UN peace operations. He contends that China's UN peacekeeping policy can to a large extent be explained by changes in China's national identity. Since China's return to the UN in 1971, China's national identity has undergone a considerable transformation, from a semi-revolutionary state in the 1970s and an integrated member of the international community in the 1980s and 1990s, to a rising power in the twenty-first century. The country's policy on UN peacekeeping has reflected these transformations. The Chinese position on UN peace operations has changed from opposition in the 1970s, to gradually expanded and reactive participation in the 1980 s and 1990 s, and finally to an increasingly active involvement in the new millennium. Yin argues that China's ambition is to contribute more than personnel and finances to UN peace operations, with this rising power also wanting to shape governance of UN operations. 
In Chapter 14, Jonathan C. Agensky turns to non-state actors and their relation to UN peace operations. He highlights practices that seek similar outcomes as UN peace operations or otherwise affect the background conditions necessary for their success. Treating South Sudan as an illustrative case study, Agensky demonstrates how the incorporation of religious institutions into global and regional aid-based governance networks enables church-based actors to pursue political, social, and structural interventions critical to UN peace operations. In doing so, he emphasises the impact of religion, aid, and governance on longer-term peacebuilding in Africa, with a view toward contributing to discussions about holistic, integrated, and people-centred approaches to sustainable peace.

In the concluding chapter, Cedric de Coning synthesises several major findings of the volume and advances the argument that we are now entering a more pragmatic era of UN peace operations. He sees peace operations as likely becoming less intrusive and more supportive of locally-led solutions. Looking forward, de Coning identifies three overarching themes. First, the degree to which a peace operation contributes to the strategic political coherence of the larger national and international effort is likely to become a key measure of its effectiveness. Second, the principle of minimum use of force is likely to remain a defining feature of peace operations. And third, the scope of peace operations mandates may be trimmed down to focus on protection, stability, and politics. $\mathrm{He}$ argues that peace operations have shown a remarkable capacity to continuously adapt to new challenges, but at the same time remained resiliently identifiable by the enduring principles of peacekeeping.

\section{REFERENCES}

Berdal, Mats, and David Malone (eds.). 2000. Greed \& Grievance: Economic Agendas in Civil Wars. Boulder: Lynne Rienner.

Burkeman, Oliver, and Xan Rice. 2006. Sudan Rejects UN Peacekeeping Plan. The Guardian, September 1. https://www.theguardian.com/world/2006/ sep/01/sudan.oliverburkeman. Accessed 14 Mar 2018.

Campbell, Susanna, David Chandler, and Meera Sabaratnam (eds.). 2011. A Liberal Peace? The Problems and Practices of Peacebuilding. London: Zed Books.

Chesterman, Simon. 2004. The Use of Force in UN Peace Operations, Peacekeeping Best Practices Unit (External Study). http://www.operationspaix.net/DATA/DOCUMENT/5808 v The_Use_of_Force_in_UN_Peace_ Operations.pdf. Accessed 14 Mar 2018. 
Collier, Paul, and Anke Hoeffler. 2004. Greed and Grievance in Civil War. Oxford Economic Papers 56: 563-595.

Cox, Robert W. 1981. Social Forces, States and World Orders: Beyond International Relations Theory. Millennium-Journal of International Studies $10(2)$ : 126-155.

Cunliffe, Philip. 2013. Legions of Peace: UN Peacekeepers from the Global South. London: Hurst.

de Coning, Cedric, Linnéa Gelot, and John Karlsrud (eds.). 2016. The Future of African Peace Operations: From the Janjaweed to Boko Haram. London: Zed Books.

de Coning, Cedric, Thomas Mandrup, and Liselotte Odgaard. 2014. The BRICS and Coexistence: An Alternative Vision of World Order. London: Routledge.

Diehl, Paul F., and Elijah PharaohKhan. 2000. Financing UN Peacekeeping: A Review and Assessment of Proposals. Review of Policy Research 17 (1): 71-104.

Essa, Azad. 2017. UN Peacekeepers Hit by New Allegations of Sex Abuse. Aljazeera, July 10. http://www.aljazeera.com/news/2017/07/peacekeepers-hit-allegations-sex-abuse-170701133655238.html. Accessed 14 Mar 2018.

Fukuyama, Francis. 1992. The End of History and the Last Man. New York: Free Press.

Green, Miranda. 2017. Haley Cheers Cuts to UN Peacekeeping: 'We're only Getting Started'. CNN Politics. http://edition.cnn.com/2017/06/29/politics/haley-on-un-cuts/index.html. Accessed 14 Mar 2018.

Heathershaw, John. 2008. Unpacking the Liberal Peace: The Dividing and Merging of Peacebuilding Discourses. Millennium: Journal of International Studies 35 (3): 597-621.

Holzgrefe, J.L., and Robert J. Keohane (eds.). 2008. Humanitarian Intervention: Ethical, Legal and Political Dilemmas. Cambridge: Cambridge University Press.

Lynch, Colum. 2013. The Blue Helmet Caste System. Foreign Policy, April 11. http://blog.foreignpolicy.com/posts/2013/04/11/the_blue_helmet_caste_ system. Accessed 14 Mar 2018.

Lynch, Colum. 2017. Trump Administration Eyes $\$ 1$ Billion in Cuts to U.N. Peacekeeping. Foreign Policy, March 23. http://foreignpolicy. com $/ 2017 / 03 / 23 /$ trump-administration-eyes-1 - billion-in-cuts-to-u-npeacekeeping. Accessed 14 Mar 2018.

Mac Ginty, Roger. 2012. International Peacebuilding and Local Resistance: Hybrid Forms of Peace. Basingstoke: Palgrave Macmillan.

Naraghi Anderlini, Sanam. 2017. UN Peacekeepers' Sexual Assault Problem. Foreign Affairs, June 9. https://www.foreignaffairs.com/articles/world/201706-09/un-peacekeepers-sexual-assault-problem. Accessed 14 Mar 2018. 
Narlikar, Amrita. 2010. New Powers: How to Become One and How to Manage Them. London: Hurst.

O’Neill, Jim. 2001. Building Better Global Economic BRICs. Global Economics Paper No. 66, Goldman Sachs, New York.

Paris, Roland. 2001. Human Security: Paradigm Shift or Hot Air? International Security 26 (2): 87-102.

Peter, Mateja. 2015. Between Doctrine and Practice: The United Nations Peacekeeping Dilemma. Global Governance: A Review of Multilateralism and International Organizations 21 (3): 351-370.

Pugh, Michael. 2004. Peacekeeping and Critical Theory. International Peacekeeping 11 (1): 39-58.

Richmond, Oliver P. 2004. UN Peace Operations and the Dilemmas of the Peacebuilding Consensus. International Peacekeeping 11 (1): 83-101.

Stedman, Stephen John. 1997. Spoiler Problems in Peace Processes. International Security 22 (2): 5-53.

Stoett, Peter J. 1999. Human and Global Security: An Exploration of Terms. Toronto: Toronto University Press.

Suhrke, Astri. 1999. Human Security and the Interests of States. Security Dialogue 30 (3): 265-276.

United Nations. 2000. Report of the Panel on United Nations Peace Operations. New York: United Nations.

United Nations. 2008. United Nations Peacekeeping: Principles and Guidelines, Department of Peacekeeping. New York: DPKO.

United Nations. 2014. Press Release: Secretary-General Appoints High-Level Independent Panel on Peace Operations, October 31. New York: United Nations.

United Nations. 2015a. Evaluation of the Enforcement and Remedial Assistance Efforts for Sexual Exploitation and Abuse by the United Nations and Related Personnel in Peacekeeping Operations, May 15. New York: UN Office of Internal Oversight.

United Nations. 2015b. Report of the High-Level Independent Panel on Peace Operations on Uniting Our Strengths for Peace: Politics, Partnership and People. New York: United Nations.

United Nations. 2017. UN Secretary-General Statement: Note to Correspondents on MINUSCA, June 21. New York: United Nations.

United Nations. 2018. Troop and Police Contributors. United Nations Peacekeeping. https://peacekeeping.un.org/en/troop-and-police-contributors. Accessed 14 Mar 2018.

Williams, Paul D., and Arthur Boutellis. 2014. Partnership Peacekeeping: Challenges and Opportunities in the United Nations-African Union Relationship. African Affairs 113 (451): 254-278. 
Open Access This chapter is licensed under the terms of the Creative Commons Attribution 4.0 International License (http://creativecommons.org/licenses/ by $/ 4.0 /$ ), which permits use, sharing, adaptation, distribution and reproduction in any medium or format, as long as you give appropriate credit to the original author(s) and the source, provide a link to the Creative Commons license and indicate if changes were made.

The images or other third party material in this chapter are included in the chapter's Creative Commons license, unless indicated otherwise in a credit line to the material. If material is not included in the chapter's Creative Commons license and your intended use is not permitted by statutory regulation or exceeds the permitted use, you will need to obtain permission directly from the copyright holder.

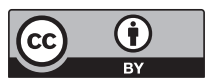

